Article

\title{
Social Work during the COVID-19 Crisis: Responding to Urgent Social Needs
}

\author{
Gisela Redondo-Sama ${ }^{1}$, Virginia Matulic ${ }^{2}$, Ariadna Munté-Pascual ${ }^{2, *}$ and Irene de Vicente ${ }^{2}$ \\ 1 Centre for Applied Ethics, Faculty of Social and Human Sciences, University of Deusto, 48007 Bilbao, Spain; \\ gisela.redondo@deusto.es \\ 2 Social Work Training and Research Section, Faculty of Education, University of Barcelona, \\ 08035 Barcelona, Spain; mmatulic@ub.edu (V.M.); ide_vicente@ub.edu (I.d.V.) \\ * Correspondence: amunte@ub.edu
}

Received: 7 September 2020; Accepted: 14 October 2020; Published: 16 October 2020

check for updates

\begin{abstract}
Social work during the COVID-19 crisis has faced one of the most challenging times to cover urgent social needs in an uncertain scenario. This study analyzes the immediate responses in social work to vulnerable groups in the first 15 days of the pandemic in Barcelona, one of the most affected areas worldwide by COVID-19. The sample for this qualitative study includes 23 semi-structured interviews with social workers from different fields of intervention, from general approaches (primary care) to specific ones (health, ageing, homeless, and justice). The data analysis followed the communicative methodology, including transformative and exclusionary dimensions, and the analytical categories focused on the impact of the COVID-19 pandemic on social services users, the organizational responses of social workers, and the impact of the interventions to cover urgent social needs of attendees. The interventions have been accompanied by an improvement in communication channels with vulnerable groups, ensuring an understanding of the situation of families and individuals, and covering the most urgent social needs. The study shows the key role of social workers from diverse social attention tools and their contribution to the sustainability of social services with a long-term impact.
\end{abstract}

Keywords: social work; COVID-19; vulnerable groups

\section{Introduction}

Social work has played a crucial role during the COVID-19 crisis, covering the most urgent social needs of vulnerable groups, such as the homeless or elderly people. However, research has been focused on health professionals, and less is known about social workers in the frontline, including those working in public health institutions. In line with scientific evidence, international and national health organizations report that vulnerable, moderate, and high-risk groups are people with health conditions that affect their immune system or older people [1-3]. According to this, in Wuhan, China, findings of adult patients with COVID-19 show that $48 \%$ had a comorbidity such as hypertension, diabetes, or coronary heart disease, and increasing death associated with older age [4]. Moreover, in the European context, in the region of Lombardy, Italy, patients requiring intensive care were majority older men, and $68 \%$ presented at least one comorbidity [5]. In addition to older or comorbid people, researchers highlight the relevance to understand the social determinants of health to fight pandemic and the social dynamics of COVID-19 [6].

The international scientific community has raised concerns linked to inequalities and COVID-19. There is evidence of previous historical crises in which the poorest populations were more affected by pandemics, and now the analysis of the COVID-19 adds to the ways by which misinformation and miscommunication disproportionally affect individuals with less access to government health 
warning [7]. The impact of the COVID-19 may differ extremely from region to region, as they have very diverse realities and opportunities to face the pandemic. In the case of the Global South, the preparedness of the informal settlements lacks basic needs (water, waste collection, etc.), and there are space constraints and other aspects such as violence that require immediate measures to protect the most vulnerable [8]. Moving from the Global South to the Global North, in the US, England, and Wales, several authors address the racial and ethnic inequalities linked to COVID-19 [9,10] or the impact on learning opportunities [11]. At the same time, challenging issues such as child abuse are also at the core of preventive actions in the COVID-19 pandemic [12].

The need for multidisciplinary research to face COVID-19 consequences has been approached in different scientific fields $[13,14]$. In this framework, social sciences and social work research contribute not only to the academic debates but also by researching on how to prevent, minimize, and respond to inequalities and cover the social urgent needs of vulnerable groups particularly affected by COVID-19. Extensive scientific developments have been published, addressing the situation of healthcare workers as well as the impact of their activity in the services provided [15], but less is known in research about social workers at the frontline. In fact, more research is needed to advance scientific knowledge about the impact of their activity on socially vulnerable populations. This work contributes to advancing scientific knowledge in this field.

\subsection{Social Vulnerabilities and Social Problems Raised in the COVID-19 Context}

Social vulnerabilities in the COVID-19 context include people living in poverty or in crowded households, with low or no access to water or sanitation, and those with low literacy skills, among others. Several studies analyzing the impact of COVID-19 have demonstrated the disproportionate effects of COVID-19 in African American communities, which reflects racial inequality and social exclusion [16,17]. Moreover, the situation in countries such as Bangladesh faces major challenges conerning social exclusion and poor living conditions in urban slums, which implies that hygiene recommendations cannot be followed [18]. In a similar vein, housing vulnerability has been approached in relation to the ways it creates inequities in the pandemic's impact [19], and inadequate housing is at the core of the analysis of vulnerable migrant workers in Singapore [20]. Research on social vulnerabilities linked to the pandemic includes poverty in several ways. For instance, child poverty has been analyzed in relation to school closures to provide actions to avoid a social crisis affecting children in low-income families [21], and the reduced access to healthcare for people of low socio-economic status has been pointed out [22]. Among the socially most vulnerable, homeless populations have been a major challenge in public health, in particular raising concerns about the emergency preparedness in lockdown cities [23].

The social vulnerabilities in the COVID-19 context and its mitigation measures relate to social problems, such as unemployment, gender violence, anxiety and depression, or homelessness. In Germany, the impact of the shutdown measures in April 2020 increased unemployment in the short-term [24] and the report "The COVID confinement measures and EU labour markets", which analyzes the restriction on activities in three EU member states (Spain, Italy, and Germany) [25], shows asymmetric effects of the COVID lockdown measures across different groups of workers. In particular, the report states that restrictions on economic activity are mainly affecting workers with lower wages and worse employment conditions, with impact significantly appearing in women and young workers. Unemployment has been associated with the increase in suicide risk, and suicide prevention during COVID-19 has increased [26], as well as the need to increase psychological support to prevent problems such as anxiety, depression, and post-traumatic stress disorder in particularly vulnerable groups [27]. In this vein, homeless people are one of the vulnerable groups more susceptible to illness or death by COVID-19 because of their physical and mental health conditions [28]. 


\subsection{Social Work in the COVID-19 Context}

The COVID-19 pandemic has had a direct impact on social work responses, including social services users, social workers, and other professionals, among other aspects. International social work organizations have mobilized efforts to respond to urgent social needs, demonstrating the values underlying the discipline. Since the beginning of the pandemic, the statements of the International Federation of Social Workers (IFSW) include aspects such as the commitment of the social work towards a better world, the ethical challenges faced by social workers, or the need to integrate transformative practices [29]. Similarly, the dissemination of publications by the International Association of Schools of Social Work [30] shows the responses from the social work to the crisis in schools, communities, and families. For instance, the IASSW collection of country reports provides the national responses to the crisis, paying special attention to the social work responses in its task to support and take care of the most vulnerable [30], such as older adults or youth in poverty.

The impact of the COVID-19 pandemic in social service users is linked to the reality faced by vulnerable groups, which may require social work interventions to improve their wellbeing and living conditions. In this respect, Swinford, Galucia and Morrow-Howell [31] apply gerontological social work perspectives to reduce the negative impacts of the pandemic in the older population, considering the heterogeneity of this group. One of the particular aspects highlighted by the authors is related to the need to confront ageism, paying special attention to the positive role of older people to the community, which can be involved in volunteer or monitoring activities with children. In this vein, Klein [32] raises certain dilemmas, debates, and questions regarding attitudes and definitions during COVID-19 concerning elderly people. The author suggests the need for a more critical approach to understanding the processes resulting in elderly people unable to communicate. Omorogiuwa [33] addresses the COVID-19 situation and older adults in Africa, focusing the analysis on social workers using mass media to promote policy change. According to this study, social workers act as agents of change and can help empower older adults using the mass media. In the arena of homelessness, social work contributions are less common than the ones appearing in the field of health, in which social health workers have also a crucial task. Benavides and Nukpezah [34] discuss the role of public administrations and the Centers for Disease Control and Prevention in the US, showing the ways to address the needs of the homeless during the pandemic, demonstrating the relevance to cooperate and share responsibilities. In the European context, the local and regional authorities and organizations have developed several initiatives, including the immediate responses of social workers in the frontline.

\subsection{Organizational Responses of Social Workers in the Frontline}

Social workers in the frontline facing COVID-19 consequences lack attention in the media, although they are coping with direct risks and preventing the needs of the vulnerable population [35]. The organizational responses of social workers to the pandemic include very diverse actions, managing challenging situations such as contacting through video calls COVID-19 patients with their loved ones in the last moments. Concerning pre-death and post-death preparedness and organization of social workers, it is important to consider their relevant role to provide psychological interventions to alleviate potential prolonged grief disorder in the pandemic context [36]. Volunteers and civil society associations have supported social workers' tasks. In England, the government achieved an excellent response from volunteers to work in social care helping to solve staff shortages, demonstrating also the need to work together between different levels of intervention and sectors [37]. Resonating with this approach, at the regional level in Spain, there are examples of collaboration between administrations and other organizations, for example, the agreement between the Catalan government and the Social Work Professional Association of Catalonia for the intervention in contexts of crisis [38]. The examples of collaboration include the support of volunteers when the scarcity of protective measures was a crucial challenge.

The personal protection equipment (PPE) for those working at the COVID-19 frontline has been one of the major problems in some countries, particularly at the beginning of the pandemic because of 
the lack of materials. In this vein, several authors identify concerns about the inadequate guidance and insufficient availability of PPE as a factor to the infection rate among healthcare workers $[39,40]$. Baker, Peckham and Seixas [41] estimate the number of workers frequently exposed to the COVID-19 infection and disease in the United States, identifying the occupations, considering community and social service occupations, and including social work. The authors identify not only the risk for these workers but also for the potential to reach their communities and families, requiring public health interventions beyond hospitals.

\subsection{Interventions to Cover Urgent Social Needs and Their Impact}

There is evidence of the key role of social work to cover urgent social needs during COVID-19, although less is known about the type of interventions developed. In this arena, it is important to highlight the effort of the IASSW to summarize the type of responses in 16 countries from different world regions [30]. In Australia, social work interventions include measures to respond to the mental health concerns during the crisis, the increase in gender violence, telehealth, and the use of other digital technologies in order to undertake social work services and provide alternative ways to reach vulnerable communities. The identification and the ways to approach communities at risk are a common aspect underpinning the interventions. In Italy, the report mentions that social workers focus on their role to guarantee essential performance and strengthen internal cohesion, and in Japan, they have allowed homeless people to stay in business hotels. Similarly, in Spain, the municipalities created spaces for homeless people, and gender violence has been at the core of some interventions. Taking into account these advancements, the analysis of the results and the impact achieved in these interventions are still underexplored.

This work aims to contribute to the analysis of immediate responses in social work during the first 15 days of the COVID-19 crisis in Barcelona and surrounding urban areas in Spain. In particular, the study provides evidence through 23 semi-structured interviews with social workers developed between 20 March to 27 March 2020. The analysis is focused on the impact of the COVID-19 pandemic in social services users, the organizational responses of social workers, and the impact of the interventions to cover urgent social needs of attendees. The results show the improvement in communication channels and the covering of the most urgent social needs as a result of the interventions. The study demonstrates the key role of social workers from diverse social attention tools and their contribution to the sustainability of social services with a long-term impact.

\section{Materials and Methods}

\subsection{The Context of the Study}

The first report of the COVID-19 situation in Spain was published on 11 February 2020 by the Instituto de Salud Carlos III, which included the first two positive investigated cases in the country [42]. The cases in the subsequent reports were increasing, and on 13 March 2020, the same public autonomous body reported that the number of confirmed cases was 4209 [43]. In this context, the Spanish Government declared the state of alarm and national lockdown through the Royal Decree 463/2020 to manage the health crisis caused by the COVID-19 [44]. The containment measures included limitations to national mobility and a list of suspended activities: leisure, artistic and cultural activities, sports, etc. Basic services, such as the activities developed by social workers, continued as they are considered as necessary. The state of alarm in Spain ended on 21 June 2020, with official data indicating a total of 246,272 confirmed cases and 28,323 deaths [45]. In this challenging context of national lockdown and confinement measures, social workers became professionals at the front line.

\subsection{Communicative Methodology Design}

The communicative methodology (hereinafter, CM) [46-48] was selected to design this study. The CM includes transformative and exclusionary dimensions in the research analysis to identify 
not only the obstacles to provide effective solutions (in this case, to cover urgent social needs) but also what works to overcome them [49]. According to the CM [50,51], the intersubjective dialogue between researchers and participants (in this case, social workers) underlined the investigation process, rethinking continuously the meaning of the questions to improve the capture of the lived moments. The research objective was to capture experiences, perceptions, feelings and opinions of social workers at the frontline in the first moments of the COVID-19 crisis in Barcelona and surrounding areas. Therefore, the research team developed a qualitative research.

The qualitative study is based on 23 semi-structured interviews with social workers collected in the first 15 days of the pandemic in Barcelona and surrounding urban areas. The testimonies include the voices of social workers from different fields of intervention, such as primary care, health, ageing, homelessness, or justice.

\subsection{Procedure}

One of the initial steps of the research team to design this work was the creation of a WhatsApp group on 17 March 2020, the International Day of Social Work. The group aimed to share information, concerns, and how to support social workers, as their activities had a direct impact on social work users. During the first conversations of the group, the possibility to develop interviews with social workers to know the immediate responses to the crisis was also shared. After two days of the group creation, the research team agreed on the ways to proceed with the investigation considering the pandemic situation, the difficulties to reach the professionals, and the potential advancements in the field. Furthermore, the continuous interaction through this group allowed us to share the preliminary potential questions and the categories to explore, sharing also by email the contacts to reach.

The research members initiated the contacts with potential participants from 20 March to 27 March by email, telephone, and WhatsApp. The long-term previous collaborations of the research team with social workers were crucial to the obtention of inspiring testimonies in a very short period and with an extremely collaborative attitude. The participative spirit of social workers with the research team was very altruistic, and they were convinced of their contribution to social work visibility during the COVID-19 crisis.

The total number of social workers reached was 28 . In the first contacts, the members of the research team noticed the challenging situation in the frontline for most of the potential testimonies. The research team anticipated this situation, and, therefore, they enabled flexibility to social workers to develop the semi-structured interviews. Moreover, the way to respond to the questions was facilitated as much as possible, offering different possibilities. Despite the difficulties, 23 semi-structured interviews were finalized in the first 15 days of the pandemic in Barcelona and surrounding urban areas, including 2 social workers infected by COVID-19. Out of the 28 contacts, 5 social workers were not able to respond because of work overload or illness.

\subsection{Participants}

The participants belong to the following different fields of intervention in social work: elderly people, health, homelessness, primary care, justice, women, disabilities, and mental health. The participants from the field of homelessness, including homeless women, is the higher one with 7 participants. The field of health, which includes palliative care and youth, has 5 participants, followed by primary care with 4 participants. There are three participants in the field of elderly people, and, finally, there is 1 participant in the fields of ex-convicts, gender violence, people with disabilities, and mental health. In terms of gender, there are 19 women and 4 men, including the case of a social work student. All the names were anonymized. Table 1 summarizes the participants' information. 
Table 1. Participants' information.

\begin{tabular}{ccccc}
\hline ID & Gender & Field of Intervention & Length of Service* & Age ** \\
\hline Jordi & Male & Elderly people & 2 & 2 \\
Pepita & Female & Health & 1 & 3 \\
Antonio & Male & Homelessness & 1 & 1 \\
Anna & Female & Primary care & 3 & 4 \\
Blanca & Female & Justice & 2 & 3 \\
Pichi & Female & Homelessness & 1 & 1 \\
Carmen & Female & Primary care & 3 & 4 \\
Claudia & Female (student) & Women & 1 & 1 \\
Hermenegilda & Female & Primary care & 4 & 4 \\
Monica & Female & Homelessness & 2 & 3 \\
Carolina & Female & Elderly people & 3 & 1 \\
Manuel & Male & Homelessness & 1 & 4 \\
Gloria & Female & Disabilities & 2 & 1 \\
Fernanda & Female & Health & 1 & 2 \\
Marta & Female & Homelessness & 2 & 1 \\
Cecilia & Female & Homelessness & 1 & 1 \\
Supmar & Female & Mental Health & 1 & 2 \\
Xana & Female & Health & 2 & 4 \\
Teresa & Female & Primary care & 4 & 2 \\
Exa & Female & Health & 2 & 4 \\
Anna & Female & Mental health & 3 & 1 \\
Tristan & Male & Elderly people & 2 & 1 \\
Pilar & Female & Homelessness & 2 \\
\hline
\end{tabular}

* Length of Service: 1: less than 10 years; 2: between 10 and 20 years; 3: between 21 and 30 years; 4: more than 30 years. ${ }^{* *}$ Age of respondents: 1 : less than $35 ; 2$ : between 36 and $45 ; 3$ : between 46 and $55 ; 4$ : more than 55 .

\subsection{Data Collection and Analysis}

The confinement context defined how to involve the participants in the study, facilitating the best suitable way for them to respond to the questions and offering the possibility to do it by email, telephone, and WhatsApp. Non-face-to-face technologies have been used in the COVID-19 context to develop qualitative research in different fields of knowledge, such as clinical psychology or medicine $[52,53]$. The dialogue between researchers and social workers underlined this process to agree about when to develop the semi-structured interview. The participants were informed about the research aim, and they provided informed consent, with details about anonymity and ethics-related issues. Throughout the data collection process, the dialogue and concerns about the situation underlined the communication, enriching the visibility of the work of the professionals in the frontline. The research team designed the questions guiding the semi-structured interviews, paying special attention to the transformative dimension of the social work. Furthermore, the initial questions addressed basic information about the field of intervention, length of service, etc. Taking into account the different strategies to develop the semi-structured interviews (telephone, etc.), the way to systematize the data was also different. In the case of the interviews by telephone, each member was responsible for recording it and taking notes. The written semi-structured interviews and WhatsApp allowed the selection of quotes. The team designed a common template to transfer and share data, including not only the defined analytical categories but also those emerging from the dialogues with the social workers.

Before the development of the semi-structured interviews, the research team defined the analytical categories to capture the impact of the COVID-19 in the attendees and the professionals. The definition was made through dialogue, and for this study, the research team selected the following: the impact of the COVID-19 pandemic on social services users, the organizational responses of social workers, and the impact of the interventions to cover urgent social needs of attendees. 


\subsection{Ethics Statement}

The research team informed the participants about the research purpose, anonymity, the voluntary basis of the study, and the permission to publish anonymously the data. The participants provided written informed consent to take part in the investigation, and the research team gave to the participants a certificate of participation.

\section{Results}

The selected analytical categories "impact of COVID-19 pandemic in social service users", "organizational responses of social workers" and "impact of the interventions to cover urgent social needs of attended people" provide an accurate and precise overview of how social work has responded to COVID-19 crisis, providing the cover of urgent social needs. In the cases in which social workers participating in the study belong to the same field of intervention, the research team has selected the most relevant exclusionary and transformative quotations for the research purpose. The analysis of the barriers (exclusionary dimension) and how social workers have overcome them (transformative dimension) shows the ways by which social work ensures the sustainability of the services.

\subsection{Impact of the COVID-19 Pandemic on Social Service Users}

In the first moments of the pandemic in Spain, the general situation faced by social service users was unforeseen by social workers, implying a barrier (exclusionary) for their unexpected role at the beginning of the pandemic. Social workers in primary care supported families that traditionally did not require such help:

'In primary care, we find social situations of families that at any other time would not have needed our intervention. Among other situations, we find: isolated people who do not have support to have food, infected parents who need [hospital] admission and are in charge of minor children without family support-the accompaniment of people who have a family member in the hospital and only know about him or her because of a doctor call once a day ... ' (Xana).

Considering this situation, the number of social service users increased with the subsequent impact on social workers' activities, in particular in the organizational responses, as discussed later on. In the quotation, the impact of the pandemic on basic needs, such as food, and the consequences in family relationships are clear. This situation implied an obstacle (exclusionary) for the development of the usual services that were required to be solved.

Moving to concrete vulnerable groups, we find that elderly people were one of the most affected in Spain by COVID-19 during the first 15 days of the crisis. Social workers illustrate the strength of this group, therefore being a transformative aspect to face the situation. It is important to highlight that the elderly in Spain is as a generation that suffered the Spanish civil war (1936-1929), and because of this, social workers express feelings such as the following:

'At first, elderly people ( ... ) did not give importance to confinement because they lived the civil war and the post-war period, and they did not give enough credibility to home confinement' (Pepita).

The reflection in this transformative extract shows the impact of previous life experiences in the COVID 19 context and the relevance to take into account the background of the attended people, as they may influence the perception of the problem.

The scientific literature also shows that another group of social service users particularly affected by the pandemic is homeless. This is highlighted by one of the professionals working in this field of intervention:

'Many social resources for homeless people have closed or limited their schedule, and this has left homeless people even more helpless and caused difficulty in accessing basic things, such as the possibility to have a shower and eat' (Antonio).

In this extract, there are several exclusionary aspects negatively influencing the provision of basic needs of the homeless, an impact of the lockdown that required the urgent action of social 
workers to transform such difficulties. As a consequence, we can state that according to previous evidence identified in the literature, the situation of homeless people reveals also in this case an increase in vulnerability. Furthermore, the scarcity of possible places for homeless people to be confined aggravated the problems of covering basic needs, adding an exclusionary element for social workers' activities. One of the social workers describe this difficulty (exclusionary) in this way:

'We forget the other population that can be exposed and that is invisible: families who lived outside during the day and had rooms only for sleep, and now this confinement is a problem; people are afraid that their landlords can throw them out, and their children make more noise than the owner or tenant of the apartment can bear' (Pepita).

People with drugs problems were also a group of social service users affected negatively in the first days of the crisis in Barcelona:

'In these moments, we find difficulties in the consumption of substances that reassured them; we cannot allow them to smoke ( ... ) it will have an impact on their character' (Blanca).

However, in the following extract there is evidence that the social workers were surprised by the positive reaction of drug consumers:

'I have been surprised by the calm and tranquility with which they are taking the situation and the way they accomplish the schedule and tasks' (Blanca).

This transformative aspect that appeared in the case of drug consumers can be also found in other extracts of the semi-structured interviews. In fact, the transformation of difficulties (transformative dimension) is a common feature to alleviate the circumstances of the social consequences of the pandemic crisis. Social workers positively highlighted the resilience of social service users:

'With regards to attendees, as always, they surprise us; they have a greater capacity to adapt to the situation than we have' (Pichi). In this extract, the social worker explains that this transformative aspect refers to homelessness, and it is not the only vulnerable group in which we find this positive attitude. Resonating with this, social workers also mentioned the positive attitude of families that attended:

'The families have understood everything very well; they are very grateful, very aware ... I have made video calls with the families so that they can see each other, and it is very exciting and they are very grateful' (Carolina).

From these two extracts, we can state that there is evidence regarding the positive attitude of social service users, therefore being a transformative dimension that facilitates the social work responses to cover social urgent needs.

\subsection{Organizational Responses of Social Workers}

One of the main organizational responses of social workers focused on protective measures, considering that they have been a major problem in public health and related services. It is important to mention that the misinformation occurred at the same time as when there was scarcity of materials to avoid infection, including contradictory protocols. Such a reality was a very important obstacle (exclusionary) for social workers:

'Disinformation is an important point in this health emergency. I believe that clear and concise communication channels should be developed for the population in social exclusion, which can reach everyone, and people can come to understand the seriousness of this situation and the need to protect oneself, to be aware of symptoms, and how to proceed if they appear' (Pilar).

In this quotation, the social worker highlights as an exclusionary aspect to develop their work not only the relevance to have information, but also to ensure communication channels to reach vulnerable groups. This is particularly important because she is not thinking about their own risk but the ways to foresee the potential infection of people in social exclusion. The strategies include the symptoms and the steps to follow in that case, going beyond the mere communication of information about the virus. In this arena, health literacy emerges as a transformative aspect to be considered in the field of health emergencies and vulnerable groups. 
The lack of personal protection equipment (PPE) underlined a major concern (exclusionary dimension) among social workers at the beginning of the pandemic:

'We started ordering material to the pharmacy, the Generalitat [regional government] and nothing... they say they won't give us material until we have a COVID-19 case' (Carolina).

As described, social workers tried to obtain the necessary equipment, but it was not possible, and the response did not allow prevention as they received the material too late, that is, after a positive case appeared and the virus had potentially spread. Therefore, the lack of PEE appears as an exclusionary aspect to provide effective solutions to cover social urgent needs. Meanwhile, in primary care, in the following extract, we can identify that social workers knew about positive COVID-19 cases, but the situation of scarcity of PPE was the same:

'Up here, many are falling: 4 doctors, 3 nurses, and 3 administrators have already fallen. And that's in the primary care center because it's worse in the hospital, the people on duty are getting very infected ... It's just that we don't have protective equipment to work with!' (Teresa).

To overcome this barrier (exclusionary dimension), social workers received the support of volunteers and civil society organizations, being an aspect that contributed to transforming difficulties into possibilities (transformative dimension):

'Protective masks are being made from the Ateneu de Fabricació de Les Corts. The "Ateneus" of Digital Manufacturing have offered their support to the Coronavirus Makers community (the network of volunteers who create medical supplies with 3D technology) for the production of some of the most demanded personal protective equipment and medical supplies by the medical community and the sectors more exposed to coronavirus infection' (Gloria).

As shown in this quotation, the network of solidarity implies the mobilization of different agents of the neighborhood, and they take into account the diversity of workers in the frontline, prioritizing the elaboration of materials for those at more risk. This extremely positive support implied an effort of coordination to ensure the identification of the needs and the quick delivery of the protective materials. The transformative dimension in the analysis included that everyone was working towards a common goal, and the social workers profoundly appreciate this help, receiving also the recognition of the people from the neighborhood.

Another obstacle (exclusionary dimension) to provide solutions to cover social needs was the fact that the guidelines from the public authorities on how to respond to the crisis were changing rapidly. These changes generated confusion in social workers, impeding the smooth development of their work: 'the guidelines have been changing very quickly. In two or three days, the day center service closes, no admission to any service is contemplated, families are no longer allowed access, apartment users go on to make all meals in their apartment to avoid contact with other residents' (Tristan).

In this extract, we find that the constant change in protocols affected negatively the services provided, in this case, influencing the welfare of elderly people about family visits and contact with peers.

Regarding coordination among social workers, it is important to highlight the use of virtual tools in many situations to ensure team communication. This allowed for communication barriers to be overcome, making the most of technological advances, thus being transformative aspect benefiting indirectly the impact of the interventions. Moreover, social workers shared emerging situations to find effective solutions, providing protection to vulnerable groups, and prioritizing the quality of the service. However, in some cases, the physical support to cover urgent social needs was mandatory, for instance, through the creation of commissions that worked efficiently (transformative dimension):

'Each Wednesday, professionals from the different support teams create a commission and distribute lots [of food] to attended people (regardless of whether they are part of their teams or not). Usually, the professionals who have private transport or those who live in the area do it to avoid public transport' (Pichi). 
In this extract, we can identify the predisposition of those social workers who have a private car to distribute food, demonstrating that solidarity emerged as a transformative aspect in the first days of the crisis.

Generally, the organization of responses required people to work remotely and physically. Any situation requiring a physical presence had professionals prepared to act. In this arena, social workers required virtual tools to attend and monitor people at risk:

'The care and monitoring of the most vulnerable families are organized both from the demands of the new needs derived from the COVID-19 infection, from the identification of other professionals, and from the prioritization of telematic monitoring of those previously identified families that as a result of the pandemic may not improve or even worsen their social situation' (Exa).

As can be identified in this extract, the social workers organized the covering of social urgent needs, taking advantage of the diversity of professionals related to social services (transformative), and the prioritization was conducted evaluating the most vulnerable cases.

\subsection{Impact of the Interventions to Cover Urgent Social Needs of Attendees}

The interventions to cover immediate food needs had an excellent impact on attendees (transformative dimension), covering basic needs and taking into account the increase in demand. Previous users of social services asked for help about food supply, and the social workers did not initially foresee such a demand, implying an obstacle to the provision of effective solutions. However, they were able to achieve, this, subsequently improving people's lives.

'Previous users came and they asked for food. We did not have this situation foreseen, but we are giving food. The situation requires us to do it' (Jordi).

In this extract, there is evidence of the transformative role of social work, as the workers were able to respond to the lack of a basic need. As shared with the researchers, the situation imposed a positive reaction, transforming the situation.

An obstacle to providing solutions was that the common services before the confinement was initiated, and, consequently, the immediate needs should be covered as much as possible without the information to do so and without details of the overview of the situation. The need of support concerning the provision of information increased among elderly people, including those living in housing for elderly people. Similarly, videoconferences with people with disabilities and their families were very transformative, as they facilitate the alleviation of distress; they could see each other with the support of a speech therapist.

In such circumstances, it is also relevant to take into account the impact of the psychological support that some social workers had on attendees; many of them felt lost in the health emergency, without a network of support and without the possibility to have access to usual services. To overcome the barrier of the lack of information (exclusionary), the interventions focused on reaching vulnerable groups in a very positive attitude (transformative):

'The effort to help others does not wane, even if it is through phone service, indirect procedures, coordination, and many phone calls and emails. We call people who live alone and who are particularly vulnerable to the virus because of their pathologies that decrease the response of the immune system' (Pepita).

This extract shows the commitment of social workers to keep basic social contact with those more vulnerable, which demonstrates the transformative role of the situation. The impact of these supportive calls enabled networks of solidarity, meaning that solidarity also represents a transformative aspect. Attendees could express their difficulties to face the situation, and they felt listened to and cared for. In the case of elderly people, the professionals remind attendees of the public health recommendations to prevent infection, they ask if they have family or neighborhood networks, and they confirm whether they have any needs. These calls have continuity, as the professionals inform the attendees that they will call again in a few days. 
Moving to the case of the interventions in homeless people reveals the transformative impact of social work activities. Fernanda expresses this in the following way:

'It is of great help for people in situations of vulnerability or who live with people at risk to have hotels that have been enabled for these people. One was led by social work, an alternative device to the isolation necessary for people who require a low level of care, or who have some lack of support or their circumstances make it difficult to return home' (Fernanda).

As can be identified in this extract, the obstacles and difficulties faced by homelessness and aggravated in the COVID-19 context were transformed through the intervention of social workers in collaboration with other agents. The possibility to accommodate people in hotels was an urgent measure managed in this case by social work, with a very positive impact on attendees, as they had a place to stay. This support included the identification of people in streets not identified before the pandemic and the most invisible appeared more visible than ever.

In the vulnerable groups of elderly people and people with disabilities, social workers faced dilemmas with other professions, and their interventions could avoid deaths. An illustrative transformative example follows:

'The most serious was when the 17 March; a woman had a fever, and the doctor of primary care said that she would be one to monitor the case (we have three doctors on staff). As the woman had a fever, the doctor ... came with a nurse ... with a morphine pack. Her words were: "fever equal to coronavirus $90 \%$, there is nothing to do, she can't be taken to the hospital". My question was ... "why? They have the same rights as other citizens" and she said, "put on morphine and on Sunday we will take the PCR test, she will no longer be there on Sunday". The response of our doctors was to ignore her indications, they knew the pathologies and crisis of this women and initiated antibiotic treatment. Today is 15 days since then; she stopped having a fever in response to the antibiotic treatment' (Carolina).

In this extract, it is demonstrated that the social work intervention in collaboration with another professional saved the life of the elderly woman. This illustrative and transformative case shows the impact of the intervention of the professionals, being extremely important for the whole society and social work as a discipline.

In cases of death, social workers were aware that they could have a very important role about accompanying and supporting families and friends. This task has not been carried out generally, and social workers report cases in which doctors were responsible for communicating cases of death to families by phone. Social work emerges as a key discipline with an impact on the emotional support for the families:

'It is important to make an effort to accompany emotionally the families of people dying that will have difficulties in mourning' (Tristan).

In this quotation, the social worker goes beyond the current pandemic situation to reflect what will be next-what they should do based on the difficulties of the families.

The pandemic crisis has raised profound concerns about how the situation has been managed, in particular regarding vulnerable populations, and whether their right to health in the same conditions as the rest of the population has been guaranteed. The need to show to society such realities is highlighted by social workers:

'One of the challenges that we have in front of this situation of emergency is to display and sensitize again to citizens the situation of those more vulnerable. Now, and always, they live in inequality; their rights are violated, again. It is needed that citizens become aware of the reality where they live' (Pichi).

Finally, in this extract, the words of the social worker identify the role that society can play about awareness of the difficulties faced by vulnerable groups. These kinds of reflections have a transformative role in raising concerns and being more socially prepared in the case of forthcoming pandemics or subsequent waves. 


\section{Discussion}

In the context of the role of social work during COVID-19, the main exclusionary aspects identified in this research are the lack of preparedness of social workers about pandemic consequences, the scarcity of PPE for social workers, the increase in basic demands (food, housing, etc.) of vulnerable groups, the closure of services for the homeless, and the changes in official guidelines and protocols to work in the COVID-19 context. These aspects implied obstacles and barriers for social workers to develop their work. The transformative aspects have provided advances to overcome these exclusionary aspects, including the positive reaction of attendees, the role of networks of solidarity to increase preparedness of the services and to provide protective materials, the use of virtual tools-not only to increase effectiveness of communication among professionals but also for ensuring communication between users and families—and, finally, the interventions that have saved lives. To sum up, this study shows the role of social work to overcome difficulties of vulnerable groups in the context of the COVID-19, integrating transformative practices [29] in collaboration with other disciplines, which is particularly relevant during the COVID-19 pandemic [54]. Dialogue and communication of social workers with vulnerable groups as well as the collaboration of civil society have emerged as some of the most transformative aspects underpinning the findings. In this arena, it is important to highlight the need to further investigate how the crisis has influenced the different cultural groups, taking into account health inequalities [55]. The social work interventions analyzed demonstrate that they have ensured that the most vulnerable groups have had food, housing, medical attention, and moral support, in particular in the cases of the homeless and elderly people. These findings are in line with previous evidence [30] and expand the existing knowledge of the transformative interventions of social work and their impact in Barcelona, Spain. The provision of food through organized networks, the identification of people in emergency situations, and the possibility of housing have avoided the increase in vulnerability of excluded or people at risk. These interventions explained by the words and feelings of social workers add value to the existing knowledge in social work research during the COVID-19 pandemic. Furthermore, the results of the transformative interventions to inform vulnerable groups about the situation resonate with previous findings [7].

The results concerning cases in which social workers have played a role to save lives are crucial to understanding the dynamics of how obstacles to providing solutions in pandemic situations (exclusionary dimension) can be transformed (transformative dimension). The implications for social work research and related disciplines can be further investigated in other regions and contexts to identify if this has occurred in other places and how. The results show the perception of social workers of their relevant role for families and friends in alleviating the impact of the death of loved ones, for instance, in analyzing resilience [56]. This finding resonates with previous evidence about the psychological interventions to alleviate potential prolonged grief disorder [36].

The results concerning the organizational responses include the creation of networks of solidarity between civil society, organization, and social workers, which have provided crucial support to the role of the community in such circumstances. Regarding the lack of PEE, the findings are in line with previous research $[39,40]$. However, based on the analysis, we can add that the roles of volunteers and civil society organizations have provided not only support to social care, but they have also provided handmade protective materials. This collaboration between different intervention levels has also played a role between social workers addressing initiatives for policy changes. In this vein, the Social Work Professional Association of Catalonia addressed a letter to the Generalitat de Catalunya [Government of Catalonia] with proposals for improvement in the social field in the post-COVID-19 scenario [57]. The Social Work Professional Association of Catalonia has monitored the situation of the professionals at the frontline, suggesting changes at the policy level to influence the structural variables that cause inequalities. The City Council of Barcelona gave the Medal of Honor to the Social Work Professional Association of Catalonia, among other organizations. This has been very important for the discipline [58] and has contributed positively to facing potential forthcoming waves of COVID-19 in the region. 
The combination of social workers developing their tasks remotely and others working physically has limited investigation until now, and it is important to further this understanding, as the results of the study show that it can prevent and improve future health emergency preparedness in diverse contexts. At the end of August 2020, Spain became one of the countries in Europe with a more increasing trend in notification rates of COVID-19 per 100,000 people [59], thus indicating the potential of a subsequent scenario faced by social workers and other professionals. The findings of this work illustrate how the situation was managed and the most relevant interventions to alleviate the impact of COVID-19 in vulnerable groups. The lessons learned will contribute to performing a better future. The analysis of the case of Barcelona and surrounding urban areas through the voices of social workers in the frontline will contribute to this aim, advancing towards the sustainability of social services in the medium and long term.

Author Contributions: Conceptualization, A.M.-P., V.M. and I.d.V.; methodology, A.M.-P., V.M. and I.d.V.; data collection, A.M.-P., V.M., and I.d.V.; data analysis, A.M.-P. and G.R.-S.; writing-original draft preparation, G.R.-S.; writing-review and editing, A.M.-P., V.M., I.d.V., G.R.-S. All authors have read and agreed to the published version of the manuscript.

Funding: This work was supported by the European Social Fund and the Spanish Agency of Research under the Ramon y Cajal grant number RYC2018-025860-I.

Conflicts of Interest: The authors declare no conflict of interest.

\section{References}

1. COVID-19: Vulnerable and High Risk Groups. Available online: https://www.who.int/westernpacific/ emergencies/covid-19/information/high-risk-groups (accessed on 12 July 2020).

2. Preguntas y Respuestas sobre el Nuevo Coronavirus (COVID-19). Available online: https: //www.mscbs.gob.es/profesionales/saludPublica/ccayes/alertasActual/nCov-China/documentos/20200312 Preguntas_respuestas_2019-nCoV.pdf (accessed on 12 July 2020).

3. People at Increased Risk. And other People Who Need to Take Extra Precautions. Available online: https://www.cdc.gov/coronavirus/2019-ncov/need-extra-precautions/index.html (accessed on 12 July 2020).

4. Zhou, F.; Yu, T.; Du, R.H.; Fan, G.H.; Liu, Y.; Liu, Z.B.; Xiang, J.; Wang, Y.M.; Song, B.; Gu, X.Y.; et al. Clinical course and risk factors for mortality of adult inpatients with COVID-19 in Wuhan, China: A retrospective cohort study. Lancet 2020, 395, 1054-1062. [CrossRef]

5. Grasselli, G.; Zangrillo, A.; Zanella, A.; Antonelli, M.; Cabrini, L.; Castelli, A.; Cereda, D.; Coluccello, A.; Foti, G.; Fumagalli, R.; et al. Baseline Characteristics and Outcomes of 1591 Patients Infected With SARS-CoV-2 Admitted to ICUs of the Lombardy Region, Italy. JAMA-J. Am. Med. Assoc. 2020, 323, 1574-1581. [CrossRef] [PubMed]

6. Harvard COVID-19 and the Most Vulnerable. Available online: https://hms.harvard.edu/news/covid-19most-vulnerable (accessed on 12 July 2020).

7. Ahmed, F.; Ahmed, N.; Pissarides, C.; Stiglitz, J. Why inequality could spread COVID-19. Lancet 2020, 5, e240. [CrossRef]

8. Corburn, J.; Vlahov, D.; Mberu, B.; Riley, L.; Caiaffa, W.T.; Rashid, S.F.; Ko, A.; Patel, S.; Jukur, S.; Martinez-Herrera, E.; et al. Slum Health: Arresting COVID-19 and Improving Well-Being in Urban Informal Settlements. J. Urban Health 2020, 97, 348-357. [CrossRef] [PubMed]

9. Pirtle, W.N.L. Racial Capitalism: A Fundamental Cause of Novel Coronavirus (COVID-19) Pandemic Inequities in the United States. Health Educ. Behav. 2020, 47, 504-508. [CrossRef]

10. Platt, L.; Warwick, R. COVID-19 and Ethnic Inequalities in England and Wales. Fisc. Stud. 2020, 41, $259-289$. [CrossRef]

11. Jaeger, M.M.; Blaabaek, E.H. Inequality in learning opportunities during Covid-19: Evidence from library takeout. Res. Soc. Stratif. Mobil. 2020, 68. [CrossRef]

12. Roca, E.; Melgar, P.; Gairal-Casadó, R.; Pulido-Rodríguez, M.A. Schools that 'Open Doors' to Prevent Child Abuse in Confinement by COVID-19. Sustainability 2020, 12, 4685. [CrossRef] 
13. Holmes, E.A.; O’Connor, R.C.; Perry, V.H.; Tracey, I.; Wessely, S.; Arseneault, L.; Ballard, C.; Christensen, H.; Silver, R.C.; Everall, I.; et al. Multidisciplinary research priorities for the COVID-19 pandemic: A call for action for mental health science. Lancet Psychiatry 2020, 7, 547-560. [CrossRef]

14. Van Bavel, J.J.; Balcker, K.; Boggio, P.S.; Capraro, V.; Cichocka, A.; Cikara, M.; Crockett, M.K.; Crum, A.J.; Douglas, K.M.; Druckman, J.N.; et al. Using social and behavioural science to support COVID-19 pandemic response. Nat. Hum. Behav. 2020, 4, 460-471. [CrossRef]

15. Fierolli, M.; Cisternino, C.; Leo, V.; Pisani, L.; Palange, P.; Nava, S. Protecting healthcare workers from SARS-CoV-2 infection: Practical implications. Eur. Respir. Rev. 2020, 29, 200068. [CrossRef]

16. Kim, S.J.; Bostwick, W. Social Vulnerability and Racial Inequality in COVID-19 Deaths in Chicago. Health Educ. Behav. 2020, 47, 509-513. [CrossRef] [PubMed]

17. Gaynor, T.S.; Wilson, M.E. Social Vulnerability and Equity: The Disproportionate Impact of COVID-19. Public Adm. Rev. 2020, 80, 832-838. [CrossRef] [PubMed]

18. Sakamoto, M.; Begum, S.; Ahmed, T. Vulnerabilities to COVID-19 in Bangladesh and a Reconsideration of Sustainable Development Goals. Sustainability 2020, 12, 5296. [CrossRef]

19. Rosenberg, A.; Keene, D.E.; Schlesinger, P.; Groves, A.K.; Blankenship, K.M. COVID-19 and Hidden Housing Vulnerabilities: Implications for Health Equity, New Haven, Connecticut. AIDS Behav. 2020, 24, 2007-2008. [CrossRef]

20. Koh, D. Migrant workers and COVID-19. Occup. Environ. Med. 2020, 77, 634-636. [CrossRef]

21. Van Lancker, W.; Parolin, Z. COVID-19, school closures, and child poverty: A social crisis in the making. Lancet Public Health. 2020, 5, E243-E244. [CrossRef]

22. Patel, J.A.; Nielsen, F.B.H.; Badiani, A.A.; Assi, S.; Unadkat, V.A.; Patel, B.; Ravindrane, R.; Wardle, H. Poverty, inequality and COVID-19: The forgotten vulnerable. Public Health 2020, 183, 110-111. [CrossRef]

23. Tsai, J.; Wilson, M. COVID-19: A potential public health problem for homeless populations. Lancet Public Health. 2020, 5, E186-E187. [CrossRef]

24. Bauer, A.; Weber, E. COVID-19: How much unemployment was caused by the shutdown in Germany? Appl. Econ. Lett. 2020, 1-6. [CrossRef]

25. Fana, M.; Tolan, S.; Torrejón, S.; Urzi Brancati, C.; Fernández-Macías, E. The COVID Confinement Measures and EU Labour Markets. Available online: https://op.europa.eu/es/publication-detail/-/publication/fe5d685b93fb-11ea-aac4-01aa75ed71a1/language-en (accessed on 1 October 2020).

26. Kawohl, W.; Nordt, C. COVID-19, unemployment, and suicide. Lancet Psychiatry 2020, 7, 389-390. [CrossRef]

27. Gonzalez-Sanguino, C.; Ausin, B.; Castellanos, M.A.; Saiz, J.; Lopez-Gomez, A.; Ugidos, C.; Munoz, M. Mental health consequences during the initial stage of the 2020 Coronavirus pandemic (COVID-19) in Spain. Brain Behav. Immun. 2020, 87, 172-176. [CrossRef] [PubMed]

28. Lima, N.N.R.; de Souza, R.I.; Feitosa, P.W.G.; Moreira, J.L.D.; da Silva, C.G.L.; Neto, M.L.R. People experiencing homelessness: Their potential exposure to COVID-19. Psychiatry Res. 2020, 288, 112945. [CrossRef] [PubMed]

29. Official IFSW Statements Relating to COVID-19. Available online: https://www.ifsw.org/updatedinformation-on-ifsw-and-the-covid-19-virus/ (accessed on 9 August 2020).

30. COVID-19 and Social Work: A Collection of Country Reports. Available online: https://www.iassw-aiets.org/ wp-content/uploads/2020/07/IASSW-COVID-19-and-Social-Work-Country-Reports-Final-1.pdf (accessed on 9 August 2020).

31. Swinford, E.; Galucia, N.; Morrow-Howell, N. Applying Gerontological Social Work Perspectives to the Coronavirus Pandemic. J. Gerontol. Soc. Work. 2020, 1-11. [CrossRef] [PubMed]

32. Klein, A. COVID-19: Los Adultos Mayores entre la "Revolución" Gerontológica y la "Expiación" Gerontológica. Res. Ageing Soc. Policy 2020, 8, 120-141.

33. Omorogiuwa, T.B.E. COVID-19 and older adults in Africa: Social workers' utilization of mass media in enforcing policy change. Int. Soc. Work 2020. [CrossRef]

34. Benavides, A.D.; Nukpezah, J.A. How Local Governments Are Caring for the Homeless During the COVID-19 Pandemic. Am. Rev. Public Adm. 2020, 50, 650-657. [CrossRef]

35. Abrams, L.S.; Dettlaff, A.J. Voices from the Frontlines: Social Workers Confront the COVID-19 Pandemic. Soc. Work. 2020, 65, 302-305. [CrossRef]

36. Johns, L.; Blackburn, P.; McAuliffe, D. Prolonged Grief Disorder and the role of social work. Int. Soc. Work. 2020, 63, 660-664. [CrossRef] 
37. Comas-Herrera, A.; Fernández, J.L.; Hancock, R.; Hatton, C.; Knapp, M.; McDaid, D.; Malley, J.; Wistow, G.; Wittenberg, R. COVID-19: Implications for the Support of People with Social Care Needs in England. J. Aging Soc. Policy 2020, 32, 365-372. [CrossRef]

38. Signem un Conveni amb Interior per Millorar la Resposta a les Afectacions Socials en les Grans Emergències. Available online: https://www.tscat.cat/continguts/noticies/signem-un-conveni-amb-interior-millorar-laresposta-les-afectacions-socials-en (accessed on 28 July 2020).

39. Thomas, J.P.; Srinivasan, A.; Wickramarachchi, C.S.; Dhesi, P.K.; Hung, Y.M.A.; Kamath, A.V. Evaluating the national PPE guidance for NHS healthcare workers during the COVID-19 pandemic. Clin. Med. 2020, 20, 242-247. [CrossRef] [PubMed]

40. Ali, S.; Noreen, S.; Farooq, I.; Bugshan, A.; Vohra, F. Risk Assessment of Healthcare Workers at the Frontline against COVID-19. Pak. J. Med. Sci. 2020, 36, S99-S103. [CrossRef] [PubMed]

41. Baker, M.G.; Peckham, T.K.; Seixas, N.S. Estimating the burden of United States workers exposed to infection or disease: A key factor in containing risk of COVID-19 infection. PLoS ONE 2020, 15, e0232452. [CrossRef]

42. Primeros Casos Investigados en España por COVID-19. Available online: https://www.isciii.es/QueHacemos/ Servicios/VigilanciaSaludPublicaRENAVE/EnfermedadesTransmisibles/Documents/INFORMES/ Informes\%20COVID-19/Informe\%20COVID-19.\%20N\%c2\%ba\%201_11febrero2020_ISCIII.pdf (accessed on 29 September 2020).

43. Informe Sobre la Situación de COVID-19 en España. Available online: https://www.isciii.es/ QueHacemos/Servicios/VigilanciaSaludPublicaRENAVE/EnfermedadesTransmisibles/Documents/ INFORMES/Informes\%20COVID-19/Informe\%20COVID-19.\%20N\%c2\%ba\%208_11marzo2020_ISCIII.pdf (accessed on 29 September 2020).

44. Real Decreto 463/2020, de 14 de Marzo, por el que se Declara el Estado de Alarma para la Gestión de la Situación de Crisis Sanitaria Ocasionada por el COVID-19. 2020. Available online: https://www.boe.es/eli/es/ rd/2020/03/14/463/con (accessed on 29 September 2020).

45. Actualización $n^{\circ}$ 143. Enfermedad por el Coronavirus (COVID-19). 21 June 2020. Available online: https://www.lamoncloa.gob.es/serviciosdeprensa/notasprensa/sanidad14/Documents/2020/210620\% 20Actualizaci\%C3\%B3n143COVID19.pdf (accessed on 29 September 2020).

46. Gomez, A.; Puigvert, L.; Flecha, R. Critical Communicative Methodology: Informing Real Social Transformation Through Research. Qual. Inq. 2011, 17, 235-245. [CrossRef]

47. Soler, M.; Gómez, A. A Citizen's Claim: Science With and for Society. Qual. Inq. 2020, 26, 943-947. [CrossRef]

48. Gómez, A.; Padrós, M.; Ríos, O.; Mara, L.; Pukepuke, T. Reaching social impact through communicative methodology. Researching with rather than on vulnerable populations: The Roma case. Front. Educ. 2019, 4, 9. [CrossRef]

49. Flecha, R. Using Mixed Methods From a Communicative Orientation: Researching With Grassroots Roma. J. Mix Methods Res. 2014, 8, 245-254. [CrossRef]

50. Gómez, A. Communicative Methodology and Social Impact. In Qualitative Inquiry in Neoliberal Times; Routledge Taylor \& Francis Group: New York, NY, USA, 2017; p. 166.

51. Flecha, R.; Soler, M. Communicative Methodology: Successful actions and dialogic democracy. Curr. Soc. 2014, 62, 232-242. [CrossRef]

52. Bryan, D.C.; Macdonald, P.; Ambwani, S.; Cardi, V.; Rowlands, K.; Willmott, D.; Treasure, J. Exploring the ways in which COVID-19 and lockdown has affected the lives of adult patients with anorexia nervosa and their careers. Eur. Eat. Disord. Rev. 2020, 1-11. [CrossRef]

53. Mukattash, T.L.; Jarab, A.S.; Abu-Farha, R.K.; Nusair, M.; Mukattash, I.L.; Obaidat, R.M.; Khdour, M.; Basheti, I. Willingness and readiness to test for COVID-19; A qualitative exploration of community pharmacists. Int. J. Clin. Pract. 2020, e13620. [CrossRef]

54. Almeida, F. The Concept Of Human2Human In The Response To COVID-19. Int. Multidiscip. J. Soc. Sci. 2020, 9, 129-151. [CrossRef]

55. Sun, S. Between personalized and racialized precision medicine: A relative resources perspective. Int. Sociol. 2020, 35, 90-110. [CrossRef]

56. Ferreira, R.; Butell, F.; Cannon, C. COVID-19: Immediate Predictors of Individual Resilience. Sustainability 2020, 12, 4685. [CrossRef] 
57. Propostes Urgents de Millora de L'àmbit Social en L'escenari post-COVID-19. Available online: https: //www.tscat.cat/download/web/2020/juliol/Carta\%20Institucional\%20Generalitat_juliol2020.pdf (accessed on 9 August 2020).

58. El Plenari del Consell Municipal Atorga les Medalles D'honor de Barcelona a Col.lectius que han Lluitat molt Directament Contra la Pandèmia de la COVID-19. Available online: https:/ajuntament.barcelona. cat/premsa/2020/07/24/el-plenari-del-consell-municipal-atorga-les-medalles-dhonor-de-barcelona-a-col\% E2\%80\%A2lectius-que-han-1luitat-molt-directament-contra-la-pandemia-de-la-covid-19/ (accessed on 9 August 2020).

59. Weekly COVID-19 Country Overview. Available online: https://covid19-country-overviews.ecdc.europa.eu/ (accessed on 29 August 2020).

Publisher's Note: MDPI stays neutral with regard to jurisdictional claims in published maps and institutional affiliations.

(C) 2020 by the authors. Licensee MDPI, Basel, Switzerland. This article is an open access article distributed under the terms and conditions of the Creative Commons Attribution (CC BY) license (http://creativecommons.org/licenses/by/4.0/). 